\title{
MIGRATION AND SOCIAL CHANGES OF ETHIC BUGIS IN KUPANG CITY, INDONESIA
}

\author{
Baco Tang \\ Faculty of Social and Political Sciences, Muhammadiyah University of Kupang, \\ East Nusa Tenggara, Indonesia \\ E-mail: bacotang375@gmail.com
}

\begin{abstract}
The ethnic Bugis migration to Kupang besides being a source of income, also as a means or means that determine access to resources power in city Kupang. Various dynamics encourage a number of people to migrate permanently to the city of Kupang. This study aims to identify the motives for migration and social change in the people of Kupang. This study was conducted at Kota Kupang East Nusa Tenggara by using a qualitative approach. Her results showed that the migration of ethnic motif Bugis because of the driving factors originating from the area of origin and the pull factors that are in the city of Kupang. The driving factor consists of low income as a result of lack of employment opportunities in the area of origin. Factors above are where broader employment opportunities, and high income and wages. Ethnic Bugis the profession trader has spawned a new social class in the structure of society. The social class of the merchant consists of the upper class (Large merchant group), middle class (medium merchant group), lower class (retailer group).
\end{abstract}

\section{KEY WORDS}

Ethic bugis, migration, social changes, social class.

Migration is generally interpreted as the movement of people geographically from one place of origin to the destination. Migration for some people is a strategic diversification of livelihood development in an effort to get out of the problem of shortages and poverty, get a job, increase income, and earn better public services (Stark, 1991; deHaan, 1999; Ellis , 2003; Skeldon, 2008; UNDP, 2009). Generally, people move past social and spatial boundaries to expand capacity and rights to improve welfare (Tirtosudarmo, 2009). They move from places with economic opportunities it feels less towards a place that is expected to have economic opportunities better. Migration itself is more synonymous with urbanization than ruralization, because more movement from village to city than from city to village and population movement activities are a cause of the process of urbanization, in addition to other causes such as the natural growth of urban residents, regional expansion, and change the status of the area from rural areas to urban areas (Purnomo, 2009: 84). Efforts to overcome the problems of life-poverty and goals other positives encourage the Indonesian people to move the population (permanent, non-permanent - both internal and international). As well with development programs in Indonesia, it has increased mobility Indonesian population (Wahyuni, 2000). Results of the 2010 Population Census recorded 5,396,419 residents or $2.5 \%$ of the population are incoming migrants risen between provinces. The percentage of risen migrants in urban areas tripled higher risk migrants in rural areas, each at $3.8 \%$ and $1.2 \%$. The two dimensions of migration are the time dimensions and regional dimensions. According to Young (1994), inter-village migration usually occurs in preindustrial conditions because of limited transportation (long distance). In the expansion, migration impact changes in the social order, as well as bringing together people who have attitudes and behavior patterns that vary (Weeks, 1978). According to White and David (2005), two of the contributing factors is the preferred place to stay and a job. Migration aside from being a source of income, it is also a mean or means that determine access to resources. According to the 2015 Kupang City BPS data, the number of Bugis ethnic groups in Kupang is 6,652. So, to reside in traditional markets, namely, market Inpres Naikoten I, Pasar Oeba, Pasar Oesapa. The success of Bugis ethnic in the city of Kupang is inseparable from the cultural values they embrace. Therefore, this study aims to analyze the motives of ethnic Bugis migration and social changes. 


\section{METHODS OF RESEARCH}

This paradigm places observation and objectivity in finding a reality or science (Guba, Lincoln, Denzin \& Linclon, 2000). This study uses the descriptive qualitative method, done in East Nusa Tenggara Kupang city. The choice of location was done purposefully on the consideration of Kupang City as a city the majority of ethnic Bugis migration in East Nusa Tenggara. Data collected includes primary data and secondary data. Primary data was obtained from observation, in-depth interviews and focus group discussions or focused group discussions (FGD). Secondary data was obtained from the Village Office, Statistics Central Agency, Population Office and previous research reports. Data analysis techniques are data collection, data analysis, data reduction, data presentation, and conclusion.

\section{RESULTS AND DISCUSSION}

Historical Study of Bungis Arrival to Kupang City. The people of South Sulawesi specifically ethnic Bugis are known to have a habit of migrating, based on the spirit of "massompe", the spirit of wandering looking for life experiences and new life in other areas in order to gain economic and knowledge opportunities and improve welfare (Lineton, 1975) also confirms that the centrifugal forces of Bugis in South Sulawesi are more dominant compared to centripetal strength. However, internal migration comes out of South Sulawesi has a tendency towards the nearest area (Kahar, 2001). Historical studies on ethnic Bugis arriving in Kupang, there are no references to the reasons why Bugis are found migrate to Kupang City. However, the second reason is identical to the actions of Bugis people those who go abroad because of si'ri problems in their home areas. Some studies show that the transfer of Bugis is driven by a number of factors, namely politics, economics, individual prestige and culture (Acciaoli, 1989; Aditjondro, 1986). Causal theory cumulative views that the social context influences migration decisions, the presence of waves of migration creates feedback that causes current migration takes place continuously (Massey, 1990). There are six factors potential that can be cumulatively affected by migration activities what happens is income distribution, land distribution, organization agricultural products, culture, regional distribution of human resources, and social change. Furthermore, factors related to gender, the satisfaction of residence, and socioeconomic status are relevant estimators towards aspirations to migrate (Creighton, 2013 ). The migration history of the first Bugis ethnic group is an immigrant tribe from the island of Muna, Southeast Sulawesi. The arrival of the Bugis tribe to the city of Kupang was estimated in 1512. Ethnic Bugis occupy the island of Sulamu. Thus a brief history of the origins of the Bugis tribes who lived and settled in the Sulamu village and the condition of the population based on the religion they embraced was the religion of Islam and their livelihoods were fishermen (Hasyim W, 2000).

Bugis Ethnic Motives Migrate to Kupang City. In the Indonesian context, the concept used in the BPS survey census, migration is the movement of residents with the aim of staying from one place to another over certain administrative boundaries (BPS, 2011). There are several reasons that are the basis of ethnic Bugis migrate. Various the results of previous studies on migration indicate that a factor the economy is a strong reason and the main driver most ethnic Bugis migrate. Factors that cause migration are distinguished become a driving factor originating from the area of origin and the pulling factor that is in the destination area. The push-pull theory explains, that the movement of the population occurs because of the results of positive and negative factors which simultaneously occur in the area of origin and destination (Lee, 1966; Abustam, 1989). The driving factor is distinguished by factors in low income, and lack of employment opportunities in the area of origin. Attractive factors that are the motives of migration are opportunities for broader employment opportunities, and high income and wages. Low income is the reason affecting ethnic Bugis migrating to Kupang. Generally, migrants work as traders in the city Kupang in the hope of increasing revenue. Migrants who just came to Kupang generally settled in relatives for a while. The availability of jobs in the city of Kupang has attracted some ethnic Bugis to migrate to that city. The existence of ethnic Bugis is also inseparable from the help of migrants who have 
already gone and helped find work in the city. Bugis ethnic income that migrates is higher than those who do not migrate.

The appeal of the city of Kupang has also influenced ethnic Bugis in migrating. Kupang City offers broader employment opportunities and higher income compared to the area of origin. Difficult employment conditions in the area of origin resulted in ethnic Bugis migrating to find work in the city of Kupang. The pattern of migration of ethnic Bugis in Kupang City is a pattern of vertical migration. Difficult employment conditions in the area of origin resulted in ethnic Bugis migrating to the city of Kupang. it means that some residents are forced to find work in Kupang. In addition, migrating has become a custom for Bugis people. The narrow employment opportunities in the agricultural sector in the area of origin caused some villagers to find work in the trade sector to the city of Kupang. Initially working in the city of Kupang was those with a middle to lower economy and low education.

Other factors this ethnic to consider to move to cities is a factor to high revenues and wages. Factors higher incomes in the city also influence to migrating. They work in the percussion area in the hope that they can get better income to increase their welfare level. Generally, they migrate in the destination area live with relatives who also circulate. Ethnic Bugis that have migrated to cities Kupang in bringing information about jobs in the city to present to relatives region of origin. When they returned to their home country, they provided information and invited relatives to work in the town. The influence of friends or relatives in the city is a source of work in the city of Kupang. The factor of friends or relatives in the city also has an important meaning for the mechanism of the occurrence of chain migration among ethnic Bugis. Information about the current spread of the city will continue to affect the number of migration.

Changes sosial ethnic Bugis migrants in Kupang. Economic development is closely related to social change and migration. Migration in this context is an important aspect of changing demographics and regional economic growth. The migration facilitates mobility between sectors and plays a role in structural change. According to Fielding (2104), the linkages between population migration and economic development usually show two-way causality. Rapid economic development in a region will result in high in-migration, and high levels of in-migration cause rapid economic growth in the region. According to Black et al., (2006), migration is a symbol of power from wage inequality, employment opportunities, or lifestyle. This ethnic make migration as a livelihood strategy to achieve prosperity symbol even surpassed the symbol. The impact of the movement of residents has been affecting social and economic life. Bugis ethnics in Kupang city currently number 6,652 and the majority work as traders and entrepreneurs. The profession has contributed to the economy of the city of Kupang. the merchant profession has also resulted in new classes in the Bugis ethnic social structure; the class is the class of financiers, middle class and retailers.

From the results of interviews with six ethnic Bugis representing elite/ financier classes, it is known that those who occupy the capital class have extensive trading networks, large businesses, and ownership of luxury vehicles. The middle class in the Bugis ethnic group in the city of Kupang is a retail class merchant with the following characteristics: having a place of business/stalls in the market, with goods traded very complete but do not have an extensive network of trade. The essential character of a growing middle class in the cities they display characteristic to perform as the bourgeoisie, but on the other side of the show also figure controller on class society. The sword class is a small retail trade that operates in the crowd. Retailers do not have much capital and extensive trading networks. the retailer class still depends on the middle class. Interdependence and mutual help have created fellow Bugis ethnic solidarity. This can be seen from the collaboration activities in the form of mutual assistance, social gathering, participation in ethnic Bugis groups in the city of Kupang. But the reality is inversely proportional to the ethnic Kupang. Ethnic Kupang cannot do anything because of limited capital and market access. Ethnic Kupang can only sell labor as workers and expect wages. 


\section{CONCLUSION}

In general, the migration factor occurs because of the driving and pulling factors. The driving factor is the factor found in the area of origin and towing factors are factors found in the destination. The occurrence of migration entry into low-income provinces due to attracting factors at the province of migration destination. The driving factor consists of a lack of low income and a lack of employment opportunities in the area of origin. Ethnic Bugis migration factor to Kupang is for employment opportunities wider, and higher incomes and wages. Ethnic Bugis whose profession of traders has given many new social classes in the structure of society. The social class of the merchant consists of the upper class (Large merchant group), middle class (medium merchant group), lower class (retailer group).

\section{REFERENCES}

1. Abustam Ml. 1989. Gerak Penduduk, Pembangunan, dan Perubahan Sosial: Kasus Tiga Komunitas Padi Sawah di Sulawesi Selatan. Jakarta (ID): UI Press.

2. Acciaoli, G. 1989. Searching for Good Fortune: The Making of a Bugis Shore Community at Lake Lindu, Central Sulawesi. Unpublished Ph.D. Thesis. Canberra: The Australian National University.

3. Aditjondro, GJ. 2006. Terlalu Bugis Sentris, Kurang Perancis. Jakarta.

4. Black R, Natali C, Skinner J. 2006. Migration and inequality. Development Research Centre on Migration, Globalisation and Poverty, University of Sussex.

5. deHaan A. 1999. Livelihoods and poverty: the role of migration -a critical review of the migration literature. Journal of Development Studies, 36(2):1-47.

6. Creighton MJ. 2013. The role of aspirations in domestic and international migration. The Social Science Journal 50 (2013): 79-88.

7. Ellis F. 2003. A livelihoods approach to migration and poverty reduction. Paper Commissioned by the Department for International Development (DFID). CNTR 034890.

8. Fielding T. 2014. Population mobility and regional development. Working Paper No 74. Sussex Centre for Migration Research. University of Sussex

9. Kahar SA. 2001. Migrasi keluar dari Sulawesi Selatan analisis data supas 1995 [Tesis]. Jakarta (ID): Universitas Indonesia.

10. Lee ES. 1984. A theory of migration: Demography 3(1): 47-57.

11. Lineton J. 1975. Pasompe' ugi': bugis migrants and wanderers. 10(1).

12. Stark O. 1991. The migration of labor. Cambridge (US): Basil Blackwell Itd.

13. Skeldon R. 2008. Migration and development: a global perspective. London (UK): Longman

14. Tirtosudarmo R. 2009. Mobility and human development in Indonesia. Human Development Research Paper 2009/19. Human Development Reports Research Paper. United Nations Development Programme.

15. United Nations Development Programme. 2009. Human development report 2009 overcoming barriers: human mobility and development. New York (US): United Nations Development Programme.

16. Wahyuni ES. 2000. The Impact of Migration Upon Family Structure and Functioning in Java, Thesis Submitted in Fulfillment of requirements the Doctor of Philosophy Degree in Population and Human Resources, Department of Geography The University of Adelaide Australia. Australia (AU).

17. White MJ, David PL. 2005. Internal Migration. In Handbooks of Population: Handbooks of Sociology and Social Researh. Poston DL and Miclin M. (Edited). America (US): Kluwer Academic/Plenum Publiser.

18. Young E. 1994. Internal Migration. Lucas D, Meyer P. Editors. In Beginning population studies. Edisi ke-2. Canberra (AU): National Center for Development Studies - ANU. 